\title{
Pembagian Area di Kampung Asuh sebagai Penerapan Pendekatan Arsitektur Perilaku
}

\author{
Fabella Andinia Setiawan dan Sri Nastiti Nugrahani Ekasiwi \\ Departemen Arsitektur, Fakultas Arsitektur, Desain dan Perencanaan, Institut Teknologi Sepuluh Nopember (ITS) \\ e-mail: nastiti@arch.its.ac.id
}

\begin{abstract}
Abstrak-Didalam merancang terdapat berbagai cara untuk melakukan pendekatan terhadap objek rancang, salah satunya adalah dengan penerapan pendekatan arsitektural pada pembagian zoning ruang dan tatanan massa pada objek rancang itu sendiri. Seperti halnya pada Kampung Asuh, yang menerapkan Pendekatan Arsitektur Perilaku dalam pembagian zoning dan area berdasarkan perilaku dari penggunanya. Kampung Asuh itu sendiri merupakan objek arstektural yang memberikan sarana perlindungan dan pembinaan untuk anak terlantar. Dimana terdapat beberapa permasalahan pada anak terlantar di Indonesia, salah satunya adalah pandangan terhadap anak terlantar yang melekat erat dengan perilaku menyimpang. Untuk mewujudkan hal tersebut, adanya perpaduan dari Pendekatan Healing Environment dirasa perlu untuk memberikan kesan alam yang dapat memberikan kenyamanan pada anak terlantar sehingga memudahkan dalam proses penyembuhan psikologis anak, dan kemudian dapat merubah perilaku anak terlantar menjadi lebih baik.
\end{abstract}

Kata Kunci-anak terlantar, arsitektur perilaku, healing environment, kampung asuh.

\section{PENDAHULUAN}

B ADAN Pusat Statistik menyebutkan bahwa Indonesia merupakan negara dengan jumlah populasi penduduk nomor 4 terbanyak di dunia dimana 4,1 juta jiwa anak masuk dalam kategori anak terlantar, menyear di seluruh provinsi di Indonesia (Gambar 1).

Pengertian anak terlantar adalah anak laki-laki atau perempuan dengan usia kurang dari 18 tahun yang karena suatu sebab orang tuanya tidak dapat memenuhi atau melalaikan kewajibannya, sehingga tidak dapat terpenuhi kebutuhannya dengan wajar, baik secara rohani, jasmani, maupun sosialnya [1]. Terdapat tiga faktor penyebab munculnya anak terlantar, antara lain; faktor ekonomi rendah, tidak terpenuhinya fungsi dari keluarga, implementasi teknis dalam perlindungan anak yang rendah. Namun terdapat satu kesamaan dari mereka meskipun penyebab menjadi anak terlantar berbeda-beda, yaitu melekat erat dengan konotasi negatif sebagai anak yang memiliki perilaku menyimpang dari yang seharusnya dan kemudian meresahkan masyarakat sekitarnya (Gambar 2).

Pemerintah telah mengajukan solusi penyelesaian atas permasalahan anak terlantar di Indonesia, diantaranya adalah dengan mendirikan rumah singgah bagi anak terlantar dan rumah asuh dengan orangtua asuh agar anak terlantar dapat terpenuhi kebutuhannya dan dapat menjalani hidup

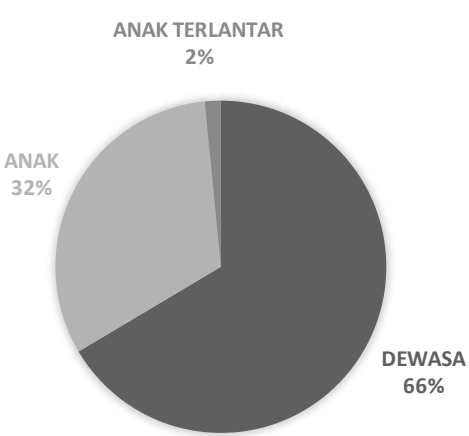

PENDUDUK INDONESIA

Gambar 1. Prosentasi jumlah anak terlantar di Indonesia (Diolah dari data BPS dan UNICEF)

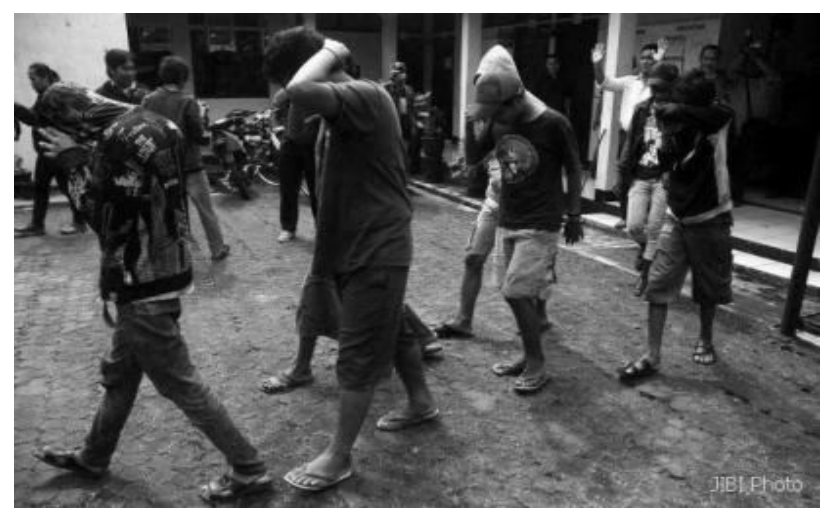

Gambar 2. Potret perilaku menyimpang pada anak terlantar.

(Sumber: https//:www.google.com)

sebagaimana mestinya. Namun pada kenyataannya, keberadaan rumah singgah ataupun rumah asuh yang ada kurang berhasil dalam menyelesaikan permasalahan tersebut .

Seperti yang dijelaskan pada Suryanto (2015) tentang analisa terhadap perilaku dari anak terlantar di rumah singgah, yang menyebutkan bahwa $15.58 \%$ dari mereka masih memiliki kepuasan hidup psikis sangat rendah (Gambar 3), yang kemudian berpengaruh pada perilakunya sehari-hari yang masih tergolong menyimpang, seperti: (a) umumnya kondisi anak masih terbawa dengan lingkungan sebelumnya, bicara masih kasar, masih sering bertengkar; (b) anak masih sulit di atur, kurang disiplin, tidak sopan; (c) suka melawan; (d) suka menceritakan masalah-masalah pribadi; (e) masih suka melakukan pelanggaran terhadap aturan yang ditetapkan yayasan/rumah singgah; (f) kecenderungan dendam jika mendapatkan hukuman fisik; (g) kecenderungan jadi pelaku 


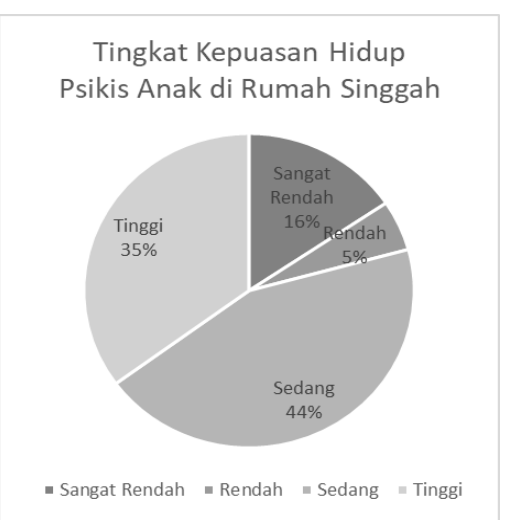

Gambar 3. Tingkat kepuasan hidup psikis anak di Rumah Singgah.

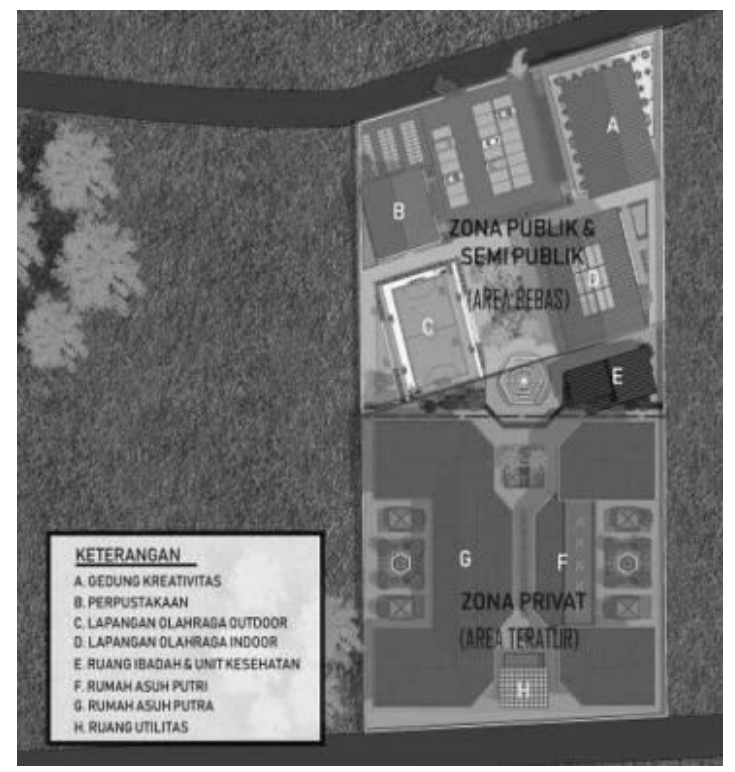

Gambar 4. Pembagian zona dan area pada kampung asuh.

dan korban perundungan/kekerasan; (h) karakter anak keras, susah di atur, karena kebanyakan dibesarkan oleh orangtua yang keras atau bahkan diterlantarkan [2].

Data tersebut menunjukkan bahwa rumah singgah yang ada belum bisa menyelesaikan permasalahan tentang perilaku menyimpang pada anak terlantar. Maka dari itu, permasalahan yang akan dibahas adalah bagaimana arsitektur dapat mengubah perilaku menyimpang pada anak terlantar.

\section{METODA PERANCANGAN}

Casare menyebutkan bahwa perilaku menyimpang disebabkan oleh faktor-faktor antara lain faktor biologis; faktor psikologis, sebab terjadinya penyimpangan ada kaitannya dengan kepribadian retak atau kepribadian yang memiliki kecenderungan untuk melakukan penyimpangan. Dapat juga karena pengalaman traumatis yang dialami seseorang; dan juga faktor sosiologis [3]. Sama halnya dengan yang terjadi pada anak terlantar, yang dapat disimpulkan bahwa faktor psikologis atau trauma yang dirasakan oleh anak terlantar dapat menjadi penyebab munculnya perilaku menyimpang dari diri mereka.

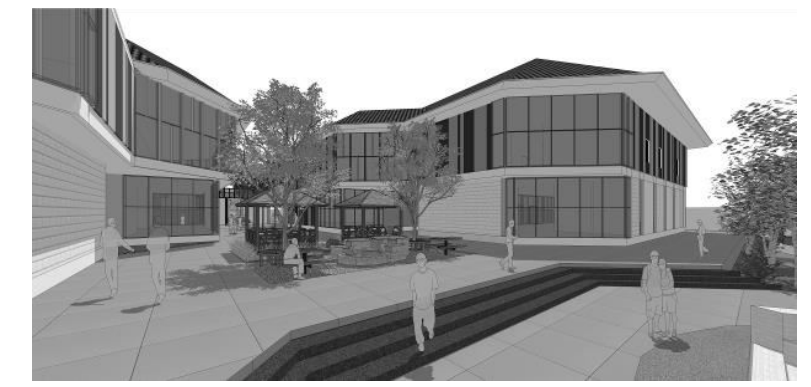

Gambar 5. Perspektif area peralihan.

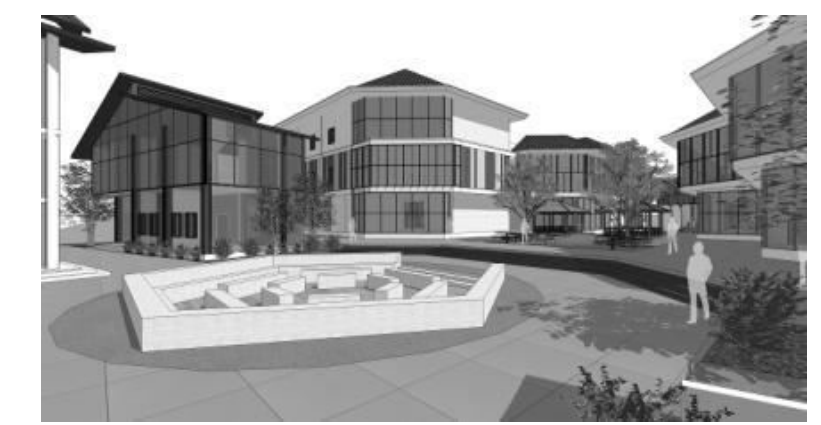

Gambar 6. Perspektif ruang berkumpul pada area peralihan.

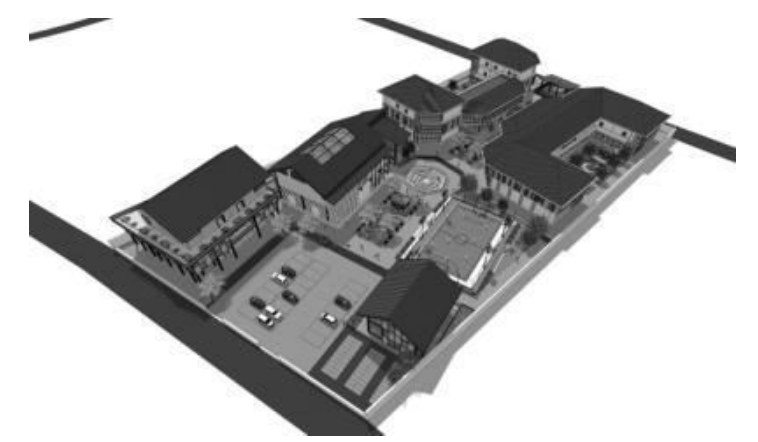

Gambar 7. Perspektif mata burung kampung asuh.

"Arsitektur tidak bisa menyembuhkan, tetapi dapat menyediakan lingkungan yang mendukung orang dalam menghadapi stres atau gejala lain dari penyakit" [4]. Dari pernyataan tersebut, arsitektur tidak bisa menyembuhkan melainkan menyediakan lingkungan atau menyediakan ruang untuk menyembuhkan.

Maka dari itu, respon arsitektural atas pernyataan tersebut adalah mengusulkan fasilitas pelayanan bagi anak terlantar berupa tempat perlindungan / tempat tinggal sementara bagi anak terlantar yang menyediakan fasilitas-fasilitas untuk memenuhi kebutuhan dari anak terlantar itu sendiri. Dibarengi dengan pendekatan arsitektur terhadap perilaku psikologis anak terlantar yang menunjang dalam pemenuhan kebutuhan perancangannya. Untuk itu dalam perancangan harus mengutamakan kebutuhan dan kebiasaan atau karakteristik dari anak.

Objek arsitektural yang dimaksud adalah Kampung Asuh. Dimana kampung asuh merupakan sebuah perkampungan yang terdiri dari beberapa bangunan berupa rumah asuh dan fasilitas penunjang dengan fungsi sebagai tempat perlindungan bagi anak terlantar di usia sekolah hingga remaja dengan kisaran usia 12-18 tahun. Juga dilengkapi fasilitas pembinaan atau 


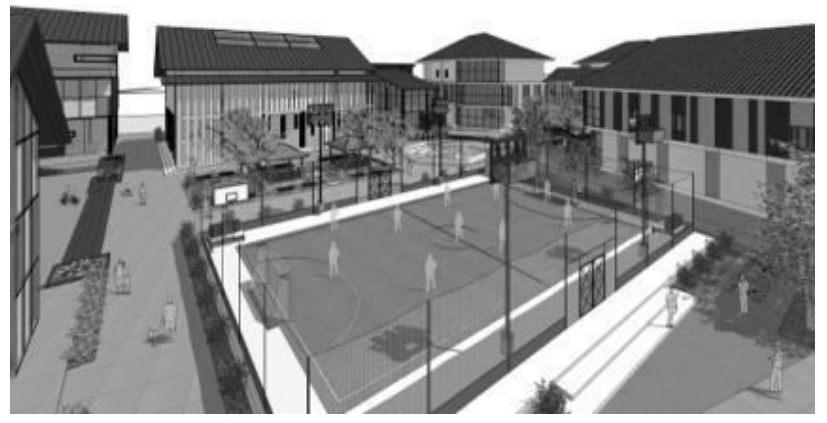

Gambar 8. Perspektif mata burung sarana olahraga outdoor.

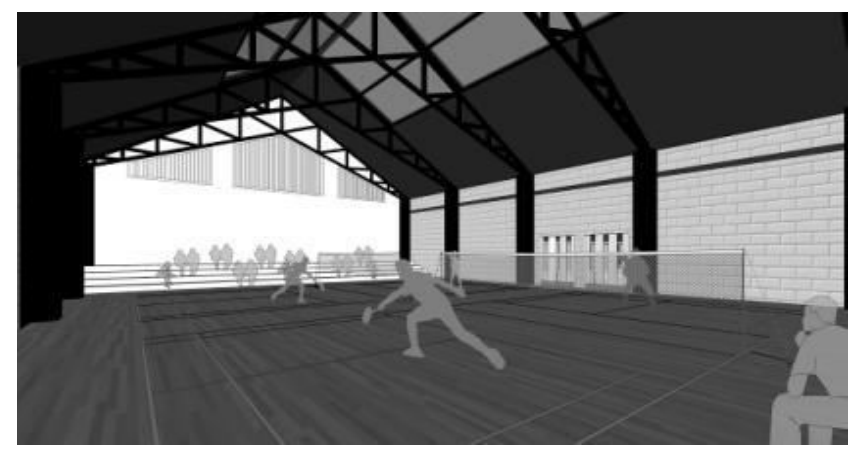

Gambar 9. Perspektif interior sarana olahraga indoor.

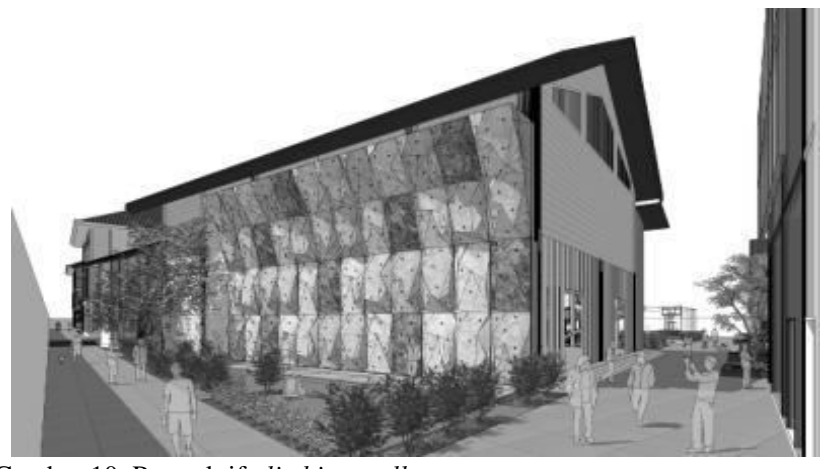

Gambar 10. Perspektif climbing wall.

tempat pengembangan kreativitas minat dan bakat bagi anak terlantar di usia tersebut.

Pendekatan yang digunakan dalam perancangan ini adalah Pendekatan Arsitektur Perilaku. Adalah pendekatan yang saling mempengaruhi antara arsitektur dengan perilaku penggunanya [5]. Arsitektur dapat mempengaruhi perilaku dari

anak terlantar sebagai penghuninya. Yaitu dengan memperhatikan kebiasaan anak terlantar sebelumnya dan merencanakan penataan ruang sesuai kebutuhannya, yang secara perlahan akan merubah kebiasaannya dan kemudian merubah perilakunya.

Tidak lepas dari fokus terhadap penyembuhan psikologis anak terlantar, arsitektur dapat merubah perilaku anak dengan menggunakan Pendekatan Healing Environment. Yaitu salah satu pendekatan yang menggunakan alam untuk membantu proses penyembuhan psikis maupun fisik [6]. Sebagaimana yang telah dijelaskan bahwa kondisi psikologis dari anak terlantar mempengaruhi bagaimana perilaku dan kebiasaan sehari-harinya. Yang kemudian perpaduan kedua pendekatan

tersebut dapat mempercepat penyembuhan psikologis anak

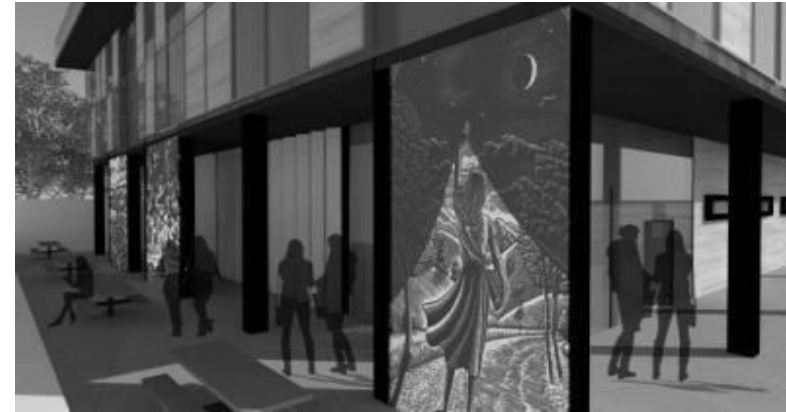

Gambar 11. Perspektif dinding mural pada gedung kreativitas.

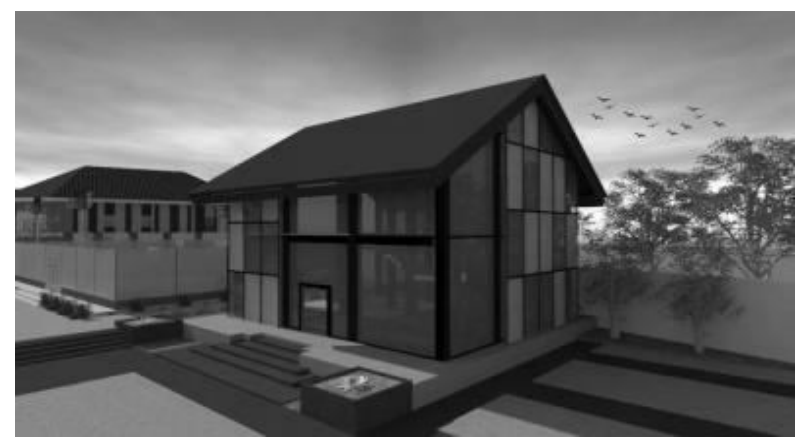

Gambar 12. Perspektif eksterior perpustakaan umum.

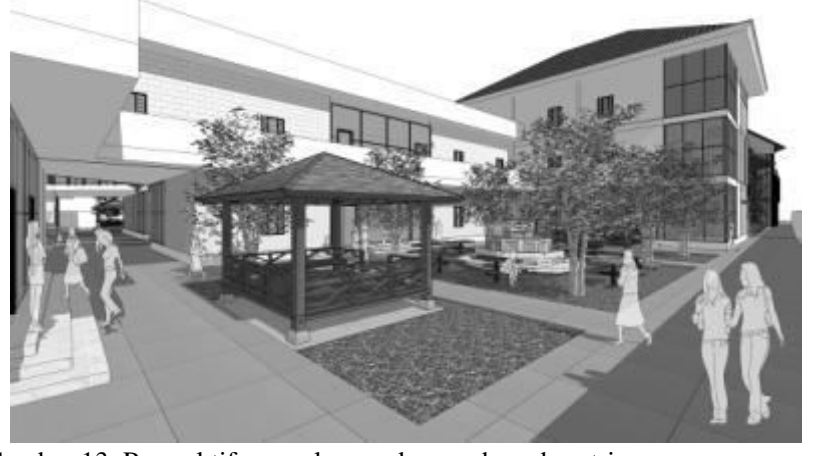

Gambar 13. Perspektif ruang luar pada rumah asuh putri.

terlantar sehingga dapat merubah perilaku menyimpang dari anak terlantar menjadi perilaku yang lebih baik.

\section{HASIL DAN EKSPLORASI}

Konsep utama pada Kampung Asuh adalah memberikan fasilitas perlindungan dan pembinaan pada anak terlantar yang dapat mengubah perilaku menyimpang anak terlantar dari sudut pandang arsitektur. Hal tersebut diwujudkan dengan cara mempelajari keinginan dan kebutuhan dari anak terlantar, dan mengaplikasikannya ke dalam perancangan objek. Salah satunya seperti memberikan sarana bagi anak terlantar untuk memenuhi keinginannya akan kebebasan, dan juga memberikan sarana untuk memenuhi kebutuhannya atas kedisiplinan yang kemudian dapat mengubah perilaku anak terlantar menjadi lebih baik. Adapun beberapa konsep yang mendukung dalam perwujudan konsep utama tersebut, antara lain:

\section{A. Konsep Zoning}

Membagi kampung asuh menjadi 2 zona utama (Gambar 4), 

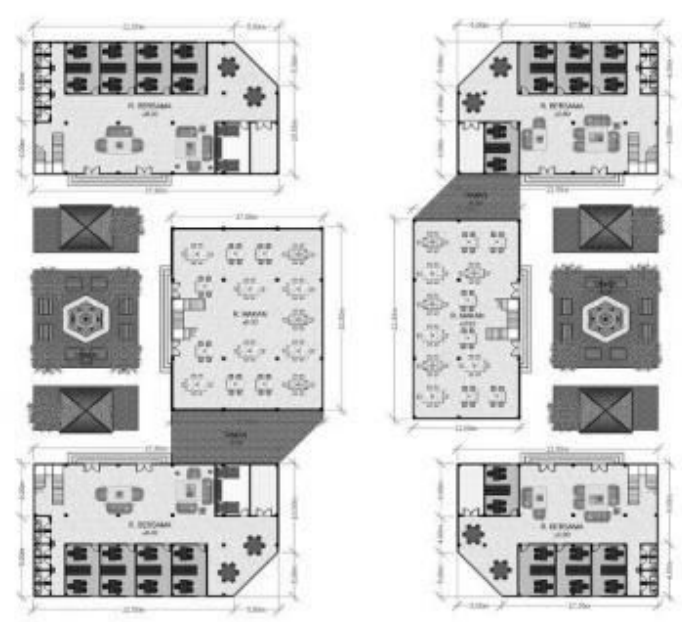

Gambar 14. Denah lantai 1 Rumah Asuh.

yaitu zona publik dan semi publik, dan zona privat. Peletakan zona publik dan semi publik di bagian luar, sebagai bentuk perlindungan terhadap anak asuh di dalam kampung asuh dari dunia luar. Hal tersebut dilakukan untuk memenuhi kebutuhan penguna atas kenyamanan privasi mereka. Dimana anak asuh membutuhkan interaksi dengan masyarakat sekitar namun juga membutuhkan privasi atas aktivitas mereka di dalam kampung asuh. Selain itu peletakan zona publik dan semi publik di bagian luar merupakan bentuk dari pemenuhan kebutuhan pengguna atas kenyamanan visual dan juga aural. Yaitu dengan membuat beberapa bangunan pada zona public lebih tinggi untuk menjadikan zona publik dan semi publik tersebut sebagai barrier kebisingan terhadap jalan raya, dan juga sebagai shading atas bangunan-bangunan yang lebih rendah di zona privat.

Selain membagi kampung asuh menjadi 2 zona utama, konsep zoning pada kampung asuh adalah membagi kampung asuh menjadi 2 area (Gambar 4), yaitu area bebas dan teratur. Berfungsi untuk memberi ruang bagi anak asuh untuk dapat merasakan kebebasan dalam mengekspresikan diri di berbagai kegiatan positif di area bebas. Namun juga memberi batasan tertentu untuk dapat melatih kedisiplinan di area teratur. Juga memberikan ruang terbuka sebagai area peralihan dari area bebas ke teratur (Gambar 5).

Seperti yang diketahui bahwa anak terlantar pada dasarnya menuntut kebebasan. Dan sebaliknya anak terlantar di kampung asuh justru dituntut untuk menjadi pribadi yang disiplin dan berperilaku baik. Maka dari itu, pembagian area di kampung asuh ini dianggap efisien untuk dapat memenuhi dua kebutuhan tersebut. Yaitu kebebasan yang diinginkan anak dalam bentuk kebebasan mengekspreksikan diri, dan juga kedisiplinan anak terlantar dengan mengikuti peraturanperaturan yang berlaku di areanya. Diantara keduanya terdapat area peralihan berupa panggung terbuka atau tempat berkumpul yang berfungsi sebagai transisi dari area bebas ke area yang teratur (Gambar 6).

Area bebas terdiri dari bangunan-bangunan yang memberikan anak asuh ruang untuk melakukan hal yang
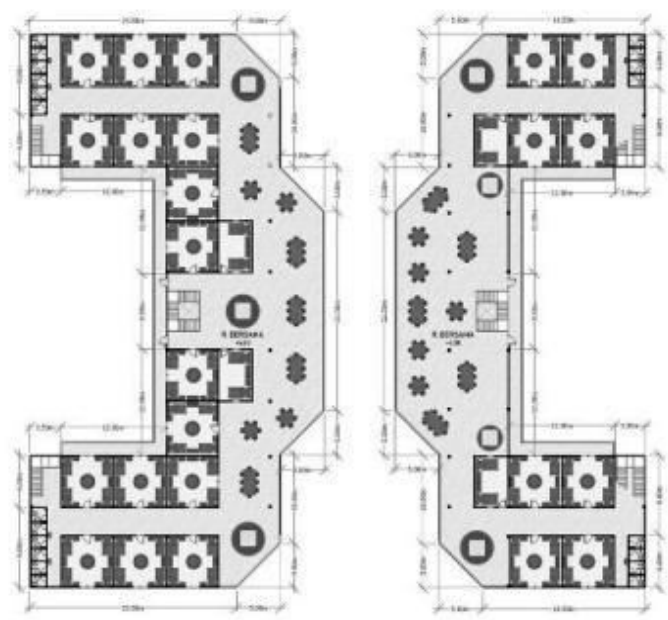

Gambar 15. Denah lantai 2 Rumah Asuh.

diinginkannya

\section{B. Konsep Tatanan Massa}

Seperti yang telah dijelaskan sebelumnya, kampung asuh dibagi menjadi 2 area utama yaitu area bebas dan area teratur. Area bebas terdiri dari bangunan-bangunan yang memberikan anak asuh ruang untuk melakukan hal yang diinginkannya, seperti gedung kreativitas, gedung bersama, perpustakaan umum, dan juga sarana olahraga outdoor. Dimana pada bagian tersebut anak asuh dapat dengan bebas mengekspresikan hal yang diinginkannya. Sedangkan pada area teratur meliputi bangunan rumah asuh, dimana pada rumah asuh membutuhkan adanya pengawasan dan peraturan-peraturan yang selanjutnya akan membuat anak asuh menjadi lebih disipilin, dan berperilaku baik (Gambar 7).

Tatanan massa yang dibutuhkan di kampung asuh ini memperhatikan kebutuhan dan aktivitas dari penggunanya. Antara lain seperti memberikan sarana untuk anak asuh agar dapat mengeksplorasikan diri di area bebas, seperti adanya sarana olahraga outdoor (Gambar 8) maupun indoor (Gambar 9), climbing wall (Gambar 10) dan dinding mural (Gambar 11), serta beberapa ruangan untuk pengembangan minat dan bakat. Juga adanya perpustakaan umum untuk mengembangkan minat baca dari anak asuh (Gambar 12).

Dengan memperhatikan karakteristik dari perilaku anak terlantar sebelumnya, nantinya akan muncul kebutuhankebutuhan ruang yang akan berfungsi untuk mengubah perilaku tersebut menjadi lebih baik. Seperti contohnya adalah perilaku menyimpang yang bersifat brutal pada anak terlantar, seperti suka mencoret-coret dinding secara illegal, ataupun suka memanjat dinding-dinding perbatasan. Perilaku tersebut dapat dialihkan menjadi hal yang lebih baik dengan memberikan sarana kepada anak terlantar, yaitu dengan adanya dinding mural dan climbing wall pada area bebas.

Adanya dinding mural pada gedung kreativitas memiliki tujuan untuk mengalihkan perilaku menyimpang pada anak asuh menjadi perilaku yang lebih bernilai positif. Yaitu dengan memberikan sarana berupa dinding untuk tempat mencoret- 


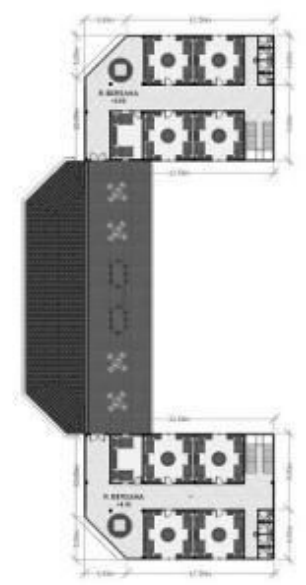

Gambar 16. Denah lantai 3 Rumah Asuh Putri.

coret sehingga lebih melatih bakat yang dimiliki oleh anak asuh (Gambar 11).

Juga adanya climbing wall yang merupakan sarana untuk mengalihkan perilaku menyimpang anak asuh ke bidang olahraga yang lebih mempunyai nilai positif. Dikelilingi oleh tanaman-tanaman berfungsi untuk memberikan efek ketenangan dan kesejukan dalam melakukan aktivitasnya (Gambar 10).

Memenuhi kebutuhan atas batasan ruang dengan lawan jenis, sebagai bentuk perlindungan privasi terhadap anak asuh. Adanya batasan ruang dengan lawan jenis dikarenakan kampung asuh bersifat tempat tinggal dimana penggunanya akan melakukan aktivitasnya untuk waktu yang cukup lama. Maka dari itu di kampung asuh ini menyediakan pembatas diantara lawan jenis namun juga memberikan tempat berkumpul antara keduanya. Contohnya dengan memberikan masing-masing rumah asuh sebuah tempat berkumpul (Gambar 13), namun juga menyediakan tempat untuk berkumpul komunal.

\section{Konsep Tatanan Ruang}

Pemilihan program ruang dan tatanan ruang pada kampung asuh ini memperhatikan kebutuhan dan aktivitas dari anak asuh. Dimana harus memperhatikan kenyamanan dari penggunanya, kenyamanan terhadap privasi, kenyamanan visual, maupun kenyamanan termal.

Seperti contohnya pada bagian rumah asuh. Penataan denah rumah asuh berdasarkan oleh kebutuhan ruang yang memperhatikan kenyamanan dari anak asuh. Salah satunya adalah peletakan ruang konseling dan ruang makan yang berada di lantai 1, yaitu berfungsi untuk kenyamanan privasi dari anak asuh terhadap dunia luar. Dimana pada ruang konseling dan ruang makan bersifat semi privat yang memungkinkan orang asing masuk ke dalamnya (Gambar 14).

Selanjutnya pada lantai 2 rumah asuh, merupakan bagian dari rumah yang memiliki tingkat privasi yang cukup tinggi. Dimana terdiri dari tempat tinggal atau ruang tidur bagi anak asuh dan ruang belajar yang memungkinkan adanya aktivitas terbanyak di dalam ruamh asuh (Gambar 15). Demikian halnya

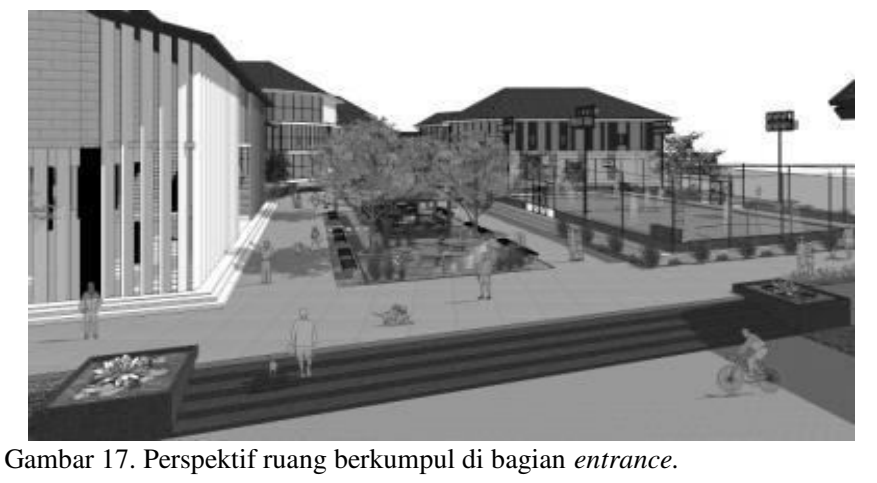

pada rumah asuh putri lantai 3 dimana memiliki tingkat privasi yang tinggi karena terdapat ruang tidur dan area belajar outdoor untuk anak asuh putri (Gambar 16).

\section{Konsep Ruang Luar}

Memaksimalkan penggunaan ruang luar sebagai tempat berkumpul untuk memberikan kesan nyaman pada anak asuh. Penggunaan ruang luar sebagai tempat berkumpul anak asuh merupakan bentuk penerapan Healing Environment yang memperhatikan efek dari alam untuk kenyamanan psikologis pengguna. Dimana kriteria dari Healing Environment yang membutuhkan penghawaan alami dan kontribusi dari alam untuk proses penyembuhan psikologis penggunanya. Yaitu dengan penataan ruang luar di beberapa titik seperti tempat berkumpul berupa taman di masing-masing rumah asuh, opera terbuka disertai beberapa tempat berkumpul di area peralihan, dan juga tempat berkumpul berupa taman di bagian entrance kampung asuh (Gambar 17).

\section{KESIMPULAN}

Adanya pembagian area di kampung asuh memberikan kemudahan untuk menyelesaikan salah satu permasalahan anak terlantar. Yaitu dengan memenuhi kebutuhan dari anak asuh. Antara lain dengan memenuhi kebutuhan dan keinginan untuk bebas, serta memenuhi kebutuhan dan keharusan untuk meninggalkan perilaku menyimpang mereka. Dengan demikian, kampung asuh akan memudahkan anak terlantar untuk berubah menjadi lebih baik.

\section{DAFTAR PUSTAKA}

[1] I. Asiani, "Panti Anak Terlantar dan Lansia di Yogyakarta," 1999. [2] Suryanto and et al, "Deteksi Dini Masalah Psikologis Anak Jalanan pada Orangtua Asuh di Rumah Singgah," Insa. J. Psikol. dan Kesehat. Ment., pp. 85-96, 2015.

[3] C. Lombroso, Crime, Its Causes and Remedies. London: W. Heinemann, 1918.

[4] F. Bloemberg et al., "Healing Environments in Radiotherapy." 2008.

[5] G. T. Moore, "Architecture and Human Behavior: The Place of Environment-Behavior Studies in Architecture," Wisconsin Archit., pp. 18-21, 1979.

[6] V. Lidayana, M. Alhamdani, and V. Pebriano, "Konsep dan Aplikasi Healing Environment dalam Fasilitas Rumah Sakit," $J$. Tek. Sipil UNTAN, pp. 417-428, 2013. 